\title{
Built Environment and Preterm Birth
}

\author{
Nikki Keene Woods, Ph.D., M.P.H. ${ }^{1}$, Linda Watson ${ }^{1}$, An-Diep T Nguyen ${ }^{2}$ \\ Wichita State University, Wichita, KS \\ ${ }^{1}$ Department of Public Health Sciences \\ ${ }^{2}$ School of Nursing
}

\begin{abstract}
Background. Preterm birth affects approximately 500,000 babies a year in the United States. One out of nine babies born in the United States deliver before 37 weeks gestation. Preterm birth can cause lifelong neurological problems, cerebral palsy, vision and hearing impairments, and developmental delay. The estimated \$26 billion a year in preterm birth related costs are staggering to the health care system. Preterm-related causes of death in 2008 together accounted for $35 \%$ of all infant deaths.

Methods. This paper is a review of the literature published (2006-2012) on the relationship between neighborhood environment and preterm birth.

Results. Neighborhood deprivation and the neighborhood environment were associated with low-birth weight and preterm birth. Examples of neighborhood deprivation include economic deprivation, social disorder, and lack of health resources. Neighborhood environment can be described as neighborhood physical deterioration, violent crime, and group density.

Conclusions. A significant association exists between the neighborhood environment and birth outcomes. More research is needed to explore interventions with a systems approach to promote healthy maternal behavior, reduce stress, and improve care for expecting mothers living in stressful neighborhood environments in order to reduce preterm births.
\end{abstract}

KS J Med 2014; 7(3):77-87.

\section{Introduction}

For many years, public health officials have known the environment impacts a person's health. According to the Centers for Disease Control and Prevention, life expectancy since 1900 in the United States has increased by approximately 40 years. ${ }^{1}$ Only seven of those years can be attributed to improvements in disease care while the other years are the result of improved prevention efforts (such as immunizations) and improved environmental conditions, including sanitation and water. The link between the nation's health and the environment is unmistakable. Several factors can create disparities in a community's health status such as socioeconomic status, ${ }^{2}$ land use and the built environment, ${ }^{3}$ race/ethnicity segregation, ${ }^{4}$ and environmental injustice. ${ }^{5}$
The built environment includes all physical aspects of the areas people live and work and influences a person's level of physical health and well-being. ${ }^{6}$ Neighborhood characteristics such as sidewalks, aesthetics, low crime, and access to affordable food promote a healthier lifestyle than neighborhoods without these characteristics. Studies have shown neighborhoods with walkability features have a direct and specific relation to the health of residents. ${ }^{7}$ Neighborhoods without sidewalks or a safe area to walk without heavy traffic restrict opportunities for physical activity. Individual personal health depends on having clean air and water, nutritious food to eat, access to healthcare, and areas free from crime and violence in which to engage in physical activity. ${ }^{7}$ 
Social capital is defined as a "community pool of human resources that is available." Circumstances that prevent or limit the availability of social capital for a community and its members can have a negative effect on the health and well-being of individual community members. Neighborhoods where social cohesion is lacking can cause individuals to have social deprivation, a lack of social support and social capital, and increased frequency of violence. These neighborhood characteristics can contribute to a lower health status in general for the community. Both expected length of life and physical quality of life are influenced by the conditions in which one is born, lives, works, ages, and dies. ${ }^{8}$

Preterm birth affects approximately 500,000 babies a year and one out of nine babies born in the United States deliver before 37 weeks gestation. ${ }^{9}$ Preterm birth can cause lifelong neurological problems, cerebral palsy, vision and hearing impairments, and developmental delay. Babies born prematurely have high risks of disability and poor health outcomes. The costs of preterm birth is staggering to the health care system. Decreasing preterm births have the potential to improve health outcomes for infants and generally improve the quality of life for families and society.

The environment in which a pregnant women lives can influence risks for preterm birth and impact pregnancy outcomes. ${ }^{10}$ Adverse birth outcomes, such as low birth weight and its determinants, preterm births, and intrauterine growth retardation, have been associated with indicators of socioeconomic status and physical environment. ${ }^{11}$ Neighborhood characteristics can affect maternal behavior and increase stress leading to complications in pregnancy and poor birth outcomes such as preterm birth. ${ }^{12}$

Previous reviews have been conducted related to the environment and adverse birth outcomes. A review and meta-analysis was conducted on articles from 1900-2010 involving observational studies on neighborhoods and pregnancy birth. This review focused on neighborhood income and low birth weight. ${ }^{13}$ Additional reviews have been completed on other aspects of the environment including epidemiological studies and health effects (including low birth weight) from 1983-2008, ${ }^{14}$ ambient air pollution and pregnancy outcomes (19812004), ${ }^{15,16}$ and risks of living near landfill sites (1982-1997). ${ }^{17}$ No previous reviews were found on the built environment and birth outcomes.

\section{Methods}

Studies for this systematic review were identified from 2006-2012 using the keywords: built environment, environment, neighborhood, low birth weight, and preterm birth. Nine databases were searched from January through May 2013, including: CINAHL, Academic Search Complete, Health Source, Social Sciences Citation Index, Science Direct, MasterFILE Premier, Proquest Nursing and Allied Health Source, and PubMed. To identify additional articles, the bibliographies of included articles were hand-searched.

Study selection. Two reviewers independently conducted a practical screen (reviewed titles and abstracts) to identify potential studies. ${ }^{18}$ A methodological screen (full text review) was completed by the same two reviewers. Inter-rater reliability was $100 \%$. Articles were reviewed if they included birth outcomes (low birth weight, preterm birth) and studied the built environment (physical characteristics). Studies were excluded if they had an international setting, focused on environment air quality or toxins, or only included psychosocial or socioeconomic factors in analysis (i.e., did not include physical characteristics of the environment). Articles on neighborhood deprivation were included 
because the definition includes a physical environment component. Reviewers extracted specific study elements including study design, environment definition, effects/conclusions, limitations, and setting (Table 1).

\section{Results}

There were 1,973 research papers originally identified using the search terms, three additional articles were identified through the hand-search. After duplicates were removed 141 articles remained; 112 were excluded after reviewing the title and/or abstract. Twenty-nine full-text articles were assessed for eligibility and 18 were excluded for not meeting inclusion criteria (e.g., related to environmental conditions, such as air quality). Eleven articles on the relationship between the built environment and birth outcomes were included (Figure 1). Ten articles were retrospective cross-sectional studies and one was prospective study (Table 1).

Neighborhood disorder. Three studies reported that neighborhood environment had an impact on preterm birth and birth weight by way of physical disorder. Women who reported higher levels of perceived social and physical disorder and perceived crime also reported higher levels of psychological distress. $^{12}$ Women who reported more experiences of racial discrimination also had higher levels of psychological distress. Objective social disorder (i.e., activities involving people, such as drug dealing, prostitution, and gangs) and perceived crime predicted psychological distress. Objective physical disorder (i.e., physical conditions of neighborhood, such as vacant housing, vacant lots and vandalism) and psychological distress predicted preterm birth. Psychological distress mediated the effect of objective social disorder and perceived crime on preterm birth. The researchers concluded that women's neighborhood environments and racial discrimination were related to psychological distress, and these factors may increase the risk for preterm birth. $^{12}$

Miranda, Messer, and Kroeger ${ }^{10}$ studied the association between the quality of the residential built environment and pregnancy outcomes among women in North Carolina. Their research found that five built environment indices (housing damage, property disorder, tenure, vacancy, and nuisance count) were associated with each of the five outcomes: preterm birth, small for gestational age, low birth weight, continuous birth weight, and birth weight percentile for gestational age.

Schempf, Strobino, and O’Campo ${ }^{19}$ examined the impact of the physical structure of neighborhoods on birth weight and evaluated mediation by psychosocial and behavioral factors. Neighborhood factors may influence birth weight by shaping maternal behavioral risks. Authors concluded neighborhood level interventions should be considered to address multiple maternal and infant health risks (e.g., tobacco use).

Neighborhood disorder and socioeconomic status. Two studies reported poorer neighborhood conditions in lower socio-economic areas were linked to preterm birth and low-birth weight. One study found after controlling for various known individual-level risk factors, pregnant women living in neighborhoods of lower median incomes lived in poorer neighborhood conditions (i.e., boarded-up housing) and had infants with both lower birthweight-for-gestational-age and shorter gestations. $^{3}$

Messer et al. ${ }^{2}$ developed socio-economic indices, defined domains of education, employment, housing, occupation, poverty, and residential stability, and using maternal age and education adjusted models. Mothers living in tracts with high unemployment, 
Table 1. Relationship between neighborhood environment and birth outcomes.

\begin{tabular}{|c|c|c|c|c|}
\hline $\begin{array}{l}\text { Study } \\
\text { (year) }\end{array}$ & $\begin{array}{l}\text { Study Design } \\
\text { (N) }\end{array}$ & $\begin{array}{l}\text { Environment } \\
\text { (Setting) }\end{array}$ & Effects/conclusions & Limitations \\
\hline $\begin{array}{c}\text { Messer et } \\
\text { al., } 2008^{2}\end{array}$ & $\begin{array}{l}\text { Retrospective, } \\
\text { cross-sectional } \\
(231,912)\end{array}$ & $\begin{array}{l}\text { Neighborhood } \\
\text { socioeconomic } \\
\text { effects (Wake } \\
\text { County, North } \\
\text { Carolina) }\end{array}$ & $\begin{array}{l}\text { Specific neighborhood- } \\
\text { level socioeconomic } \\
\text { features may be especially } \\
\text { influential to health } \\
\text { outcomes }\end{array}$ & $\begin{array}{l}\text { Use of census data; } \\
\text { no information on } \\
\text { length of residence }\end{array}$ \\
\hline $\begin{array}{l}\text { Farley et } \\
\text { al., } 2006^{3}\end{array}$ & $\begin{array}{l}\text { Retrospective, } \\
\text { cross-sectional } \\
(105,111)\end{array}$ & $\begin{array}{l}\text { Neighborhood } \\
\text { environment and } \\
\text { adverse birth } \\
\text { outcomes } \\
\text { (Louisiana) }\end{array}$ & $\begin{array}{l}\text { Measures of neighborhood } \\
\text { economic conditions } \\
\text { associated with both fetal } \\
\text { growth and length of } \\
\text { gestation independent of } \\
\text { individual-level factors }\end{array}$ & $\begin{array}{l}\text { Cross-sectional } \\
\text { study; lack of actual } \\
\text { data on retail outlets }\end{array}$ \\
\hline $\begin{array}{l}\text { Vinikoor- } \\
\text { Imler et al., } \\
2011^{7}\end{array}$ & $\begin{array}{l}\text { Retrospective, } \\
\text { direct } \\
\text { observation } \\
(39,000)\end{array}$ & $\begin{array}{c}\text { Physical } \\
\text { incivilities } \\
\text { (neighborhood } \\
\text { degradation), } \\
\text { social spaces, } \\
\text { walkability, } \\
\text { borders and } \\
\text { arterial features } \\
\text { (North Carolina) }\end{array}$ & $\begin{array}{l}\text { Certain neighborhood } \\
\text { conditions were associated } \\
\text { with maternal health } \\
\text { behaviors and pregnancy } \\
\text { outcomes }\end{array}$ & $\begin{array}{l}\text { Not generalizable to } \\
\text { entire population; } \\
\text { lack of minority } \\
\text { women other than } \\
\text { black }\end{array}$ \\
\hline $\begin{array}{l}\text { Miranda et } \\
\text { al., } 2012^{10}\end{array}$ & $\begin{array}{l}\text { Retrospective, } \\
\text { direct } \\
\text { observation, } \\
\text { cross-sectional } \\
(17,000)\end{array}$ & $\begin{array}{l}7 \text { indices of } \\
\text { residential built } \\
\text { environment } \\
\text { (Durham, North } \\
\text { Carolina) }\end{array}$ & $\begin{array}{l}\text { Relationship between } \\
\text { quality of built } \\
\text { environment/birth } \\
\text { outcomes }\end{array}$ & $\begin{array}{l}\text { Data quality } \\
\text { limitations; } \\
\text { residential mobility; } \\
\text { omitted maternal } \\
\text { smoking; may lie on } \\
\text { causal paths which } \\
\text { would adjust away } \\
\text { from effect } \\
\text { researchers trying to } \\
\text { observe; cross- } \\
\text { sectional study }\end{array}$ \\
\hline $\begin{array}{l}\text { Giurgescu } \\
\text { et al., } \\
2012^{12}\end{array}$ & $\begin{array}{c}\text { Prospective, } \\
\text { cross-sectional } \\
(72)\end{array}$ & $\begin{array}{l}\text { Neighborhood } \\
\text { environment, } \\
\text { racial } \\
\text { discrimination, } \\
\text { psychological } \\
\text { distress and } \\
\text { preterm birth } \\
\text { (Chicago, } \\
\text { Illinois) }\end{array}$ & $\begin{array}{l}\text { Objective physical } \\
\text { disorder and psychological } \\
\text { distress predicted preterm } \\
\text { birth; neighborhood } \\
\text { environment and racial } \\
\text { discrimination were } \\
\text { related to psycho-logical } \\
\text { distress, these factors may } \\
\text { increase risk for preterm } \\
\text { birth }\end{array}$ & $\begin{array}{l}\text { Small sample size; } \\
\text { limited variability } \\
\text { for the objective } \\
\text { neighborhood } \\
\text { measures; cross- } \\
\text { sectional study }\end{array}$ \\
\hline
\end{tabular}




\begin{tabular}{|c|c|c|c|c|}
\hline $\begin{array}{l}\text { Schempf et } \\
\text { al., } 2009^{19}\end{array}$ & $\begin{array}{l}\text { Retrospective, } \\
\text { cross-sectional } \\
\text { (726) }\end{array}$ & $\begin{array}{l}\text { Neighborhood } \\
\text { environment on } \\
\text { birth weight } \\
\text { (Baltimore, } \\
\text { Maryland) }\end{array}$ & $\begin{array}{l}\text { Neighborhood structures } \\
\text { and processes may have } \\
\text { impact }\end{array}$ & $\begin{array}{l}\text { Inability to } \\
\text { disentangle the } \\
\text { effects of specific } \\
\text { neighborhood } \\
\text { structures and } \\
\text { distinguish effects } \\
\text { on fetal growth } \\
\text { restriction versus } \\
\text { gestational age; } \\
\text { cross-sectional study }\end{array}$ \\
\hline $\begin{array}{l}\text { Debbink et } \\
\text { al., } 2011^{20}\end{array}$ & $\begin{array}{l}\text { Retrospective, } \\
\text { cross-sectional } \\
(109,238)\end{array}$ & $\begin{array}{l}\text { Influence of } \\
\text { racial residential } \\
\text { segregation } \\
\text { (Michigan) }\end{array}$ & $\begin{array}{l}\text { Increased odds of low } \\
\text { birth weight }\end{array}$ & $\begin{array}{l}\text { Lacked individual- } \\
\text { level data; cross- } \\
\text { sectional study }\end{array}$ \\
\hline $\begin{array}{l}\text { Kramer et } \\
\text { al., } 2010^{21}\end{array}$ & $\begin{array}{c}\text { Retrospective, } \\
\text { cross-sectional } \\
(6,180,544)\end{array}$ & $\begin{array}{l}\text { Residential } \\
\text { isolation } \\
\text { (231 US } \\
\text { Metropolitan } \\
\text { statistical areas) }\end{array}$ & $\begin{array}{l}\text { Black women, isolation is } \\
\text { associated with very } \\
\text { preterm birth and } \\
\text { moderately preterm birth }\end{array}$ & $\begin{array}{l}\text { Lack of information } \\
\text { on important } \\
\text { variables; cross- } \\
\text { sectional study }\end{array}$ \\
\hline $\begin{array}{l}\text { O’Campo } \\
\text { et al., } \\
2008^{23}\end{array}$ & $\begin{array}{l}\text { Retrospective } \\
(102,377)\end{array}$ & $\begin{array}{l}\text { Neighborhood } \\
\text { deprivation } \\
\text { (Maryland, } \\
\text { Michigan, North } \\
\text { Carolina, } \\
\text { Pennsylvania) }\end{array}$ & $\begin{array}{l}\text { Significant but moderate- } \\
\text { to-weak association } \\
\text { between neighborhood } \\
\text { deprivation and preterm } \\
\text { birth }\end{array}$ & $\begin{array}{l}\text { Limited ability to } \\
\text { adjust for } \\
\text { individual-level } \\
\text { confounders; quality } \\
\text { of maternal data on } \\
\text { birth certificates; } \\
\text { lack of length of } \\
\text { residence data }\end{array}$ \\
\hline $\begin{array}{l}\text { Holzman et } \\
\text { al., } 2009^{24}\end{array}$ & $\begin{array}{l}\text { Retrospective, } \\
\text { cross-sectional } \\
(182,938)\end{array}$ & $\begin{array}{l}\text { Maternal age, } \\
\text { neighborhood } \\
\text { deprivation } \\
\text { (Maryland, } \\
\text { Michigan, North } \\
\text { Carolina, } \\
\text { Pennsylvania) }\end{array}$ & $\begin{array}{l}\text { Support "weathering” } \\
\text { hypothesis }\end{array}$ & $\begin{array}{l}\text { Bias by self- } \\
\text { selection; cross- } \\
\text { sectional study }\end{array}$ \\
\hline $\begin{array}{l}\text { Janevic et } \\
\text { al., } 2010^{25}\end{array}$ & $\begin{array}{l}\text { Retrospective, } \\
\text { cross-sectional } \\
(492,332)\end{array}$ & $\begin{array}{c}\text { Neighborhood } \\
\text { deprivation and } \\
\text { preterm } \\
\text { birth/birth weight } \\
\text { (New York City) }\end{array}$ & $\begin{array}{l}\text { Preterm birth and low } \\
\text { birth weight was } \\
\text { associated with highest } \\
\text { quartile of deprivation }\end{array}$ & $\begin{array}{l}\text { Limitations of birth } \\
\text { certificate data may } \\
\text { have over-adjusted } \\
\text { by controlling } \\
\text { individual-level } \\
\text { characteristics (e.g., } \\
\text { smoking) }\end{array}$ \\
\hline
\end{tabular}

low education, poor housing, low proportion of managerial or professional occupation, and high poverty were associated with increased odds of preterm birth for nonHispanic white women at most sites. Among non-Hispanic black women, similar associations were noted for tract-level low education, high unemployment, low occupation, and high poverty, but the effect estimates were generally smaller than those seen for white women. The authors suggest that specific neighborhood-level socioeconomic features may be especially influential to health outcomes. These socio-economic 


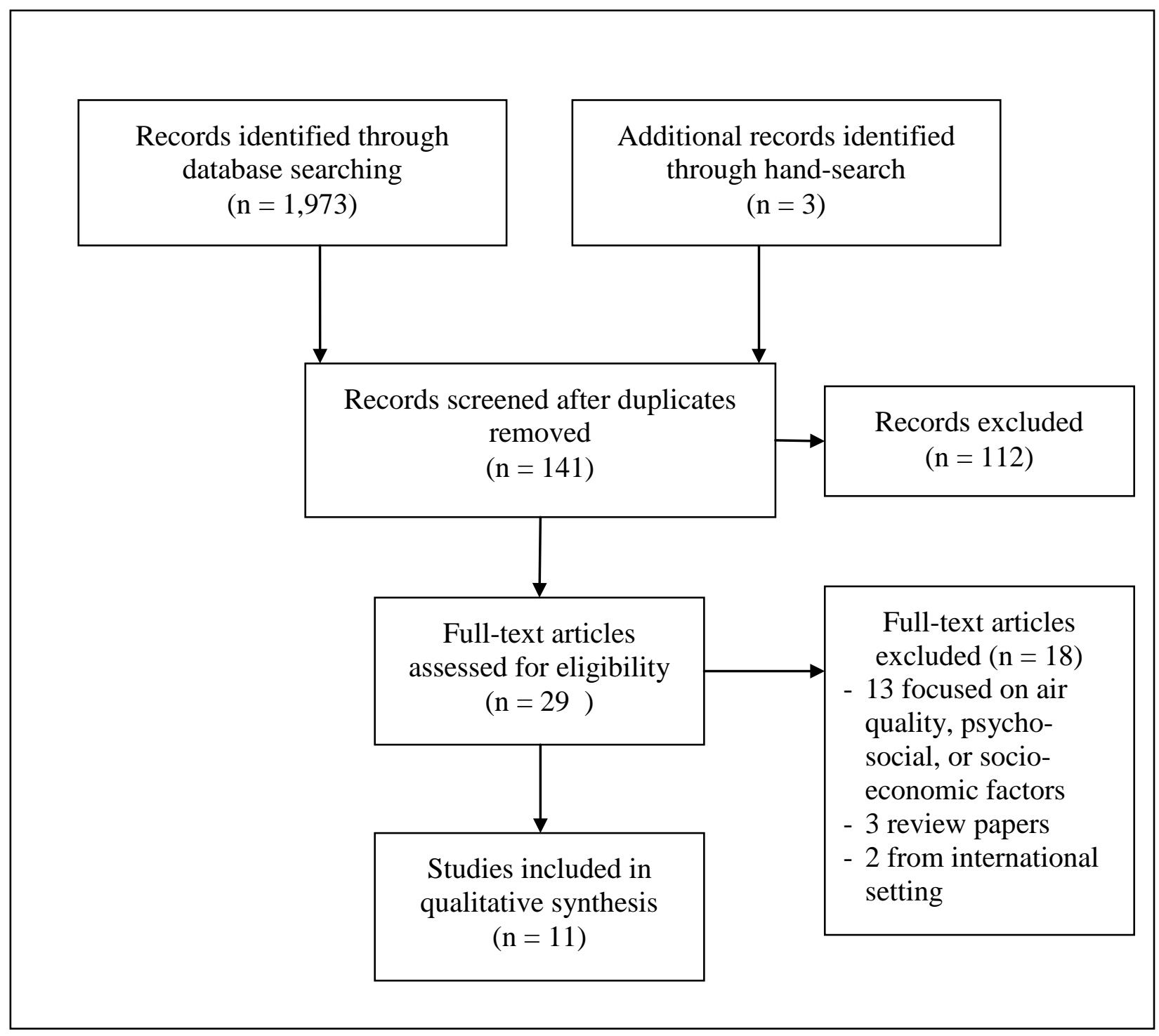

Figure 1. Flow diagram of study selection.

domains represent potential targets for intervention or policy efforts designed to improve maternal and child health and reduce health disparities.

Neighborhood diversity. Three studies reported an association between birth outcomes and whether an individual is a racial or ethnic majority in the local community. Debbink and Bader ${ }^{20}$ studied racial residential segregation and low birth weight in Michigan's Metropolitan Areas. Living in a black segregated area was associated with increased odds (odds ratio
[OR $]=1.15$; 95\% confidence interval $[\mathrm{CI}]=$ 1.03, 1.29; $\mathrm{p}<0.05$ ) of low birth weight after adjusting for individual- and tract-level measures. The authors suggested the association between low birth weight and racial segregation was attributable primarily to increased risk of intrauterine growth restriction. Similarly, residential isolation segregation (a measure of residential interracial exposure) was reported to be associated with rates of preterm birth experienced by black women. ${ }^{21}$ 
Messer and colleagues ${ }^{22}$ reported nonHispanic black women were more likely than non-Hispanic white women to deliver preterm (12.8\% versus 6.7\%), live in economically deprived block groups (42.2\% versus $19.3 \%$ in the highest deprivation quartile), and experience more crime (32.0\% versus $3.8 \%$ in the highest violent-crime-rate quartile). In unadjusted models, quartiles of violent, theft, property, and vice crimes were associated with preterm birth. In adjusted models, living in very high violent-crimerate block-group quartiles was suggestive of increased odds of preterm birth for white and black non-Hispanic women. The authors concluded differential neighborhood exposures may contribute to racial disparity in preterm birth outcomes. $^{22}$

Neighborhood deprivation. Five studies reported neighborhood deprivation was reported to be associated with low-birth weight and preterm birth. All studies included the same neighborhood deprivation index. Examples of neighborhood deprivation included economic deprivation, social disorder, and lack of health resources. O'Campo et al. ${ }^{23}$ found deprivation at the neighborhood level was significantly associated with increased risk of preterm birth among both non-Hispanic white women and non-Hispanic black women.

Holzman, Eyster, and Kleyn ${ }^{24}$ compared the association between advancing maternal age and risk of preterm delivery across four groups (black smokers, black nonsmokers, white smokers, and white nonsmokers) and within the context of neighborhood deprivation levels. For multiparous women, a significant age-related increase in preterm delivery was found. The adjusted odds ratio per five-year age increase was 1.31 for black smokers, 1.11 for black nonsmokers, and 1.16 for white smokers. For each group, the odds ratio increased as neighborhood deprivation increased. The results support the "weathering"' hypothesis or accelerated aging, suggesting that black women, women with high-risk behaviors, and women living in high deprivation neighborhoods may develop " accelerated aging"' that increases preterm delivery risk.

Janevic and colleagues ${ }^{25}$ reported preterm birth outcomes were greater for the highest quartile of neighborhood deprivation. Preterm birth rates also varied by ethnicity where the greatest magnitude of preterm birth was reported for Hispanic Caribbean women and black women for low birth weight. Authors called for research to investigate birth outcome differences among individual ethnicity and cultures related to neighborhood deprivation. ${ }^{25}$

\section{Discussion}

Physical disorder, neighborhood deprivation, and neighborhood racial diversity impacted maternal health behavior and healthy birth outcomes. Mothers living in neighborhoods with a lower median income, low education, high unemployment and high poverty reported higher rates of infants with preterm birth and lower birth weight. Many factors of the environment the mother is exposed to during pregnancy can impact prenatal health, which also affects birth outcomes. ${ }^{4,23,24}$ Despite efforts to reduce the gap between blacks and whites, racial disparities in adverse birth outcomes, specifically infant mortality, low birth weight, and preterm birth, continue to persist in the United States. ${ }^{23}$ Confounding variables, such as socioeconomic status or maternal education, were identified in adjusted models of the evaluated studies based on theoretical associations. ${ }^{21,25}$ Studies used stratification and multivariate analyses to control for these confounding variables.

Prior research established associations between pregnancy outcomes and specific neighborhood characteristics, including economic disadvantage, violent crime, and 
racial/ethnic segregation. ${ }^{4}$ Seven community factors of the built environment were identified previously as important in improving health outcomes for disadvantaged and vulnerable communities: transportation/business investments, access to food, access to health care, access to housing, air and water quality/ uncontaminated land, socioeconomic factors, and reduced residential segregation. ${ }^{5}$ This review supplemented previous findings and highlighted the importance of the physical structure and quality of the built environment in relation to birth outcomes.

Clarifying ways that neighborhoods and the built environment influence health behaviors and outcomes is important for identifying policies and preventable care procedures needed to support efforts to reduce preterm birth. ${ }^{7}$ Features of the built environment partially may explain the longobserved associations between sociodemographic conditions and adverse health. ${ }^{10}$ Public health and environmental scientists are focused on the interdependent relationship between the built environment and health disparities. ${ }^{5}$ Neighborhoods can influence individual-level behaviors that may influence the amount of stress a woman experiences during her pregnancy, which also may be associated with her decisions regarding the use of alcohol, tobacco, and other drugs, her ability to access adequate nutrition, and her sexual behavior. ${ }^{13}$

This type of research may be beneficial for healthcare workers to aid in identification of high-risk patients, providing an opportunity to connect mothers to community resources and part of a comprehensive solution needed to address the preterm birth rate in Kansas. According to Institute of Medicine, the annual societal economic burden associated with preterm birth in the United States was at least \$26.2 billion in 2005 , or $\$ 51,600$ per infant born preterm. ${ }^{26}$ Medical care services contributed $\$ 16.9$ billion to the total cost and maternal delivery costs contributed another \$1.9 billion. Lowering the number of preterm births will save healthcare dollars at both state and federal levels.

Interventions to reduce the morbidity and mortality related to preterm birth can be classified as primary (directed to all women before or during pregnancy), secondary (aimed at eliminating or reducing risk in women with known risk factors), or tertiary (initiated after parturition with a goal of preventing delivery or improving outcomes for preterm infants). ${ }^{27}$ Iams et al. ${ }^{27}$ reviewed preterm interventions and found that organized systems of perinatal care, commonly termed regional perinatal networks, in which mothers who are likely to deliver preterm are cared for by obstetric and neonatal specialists and appropriate equipment during labor, delivery, resuscitation, and newborn care, consistently have been associated with the greatest survival rates. Applying regional perinatal networks in Kansas with an emphasis on identifying women living in poor quality neighborhoods could address health disparities and improve preterm birth rates.

Communities should continue to connect high-risk pregnant women to social services through a public health network. These interventions may include support groups and mentoring programs to women living in poor quality built neighborhoods. Hobel, Goldstein, and Barrett ${ }^{28}$ found that women who had multiple types of social support from difference sources had infants with the highest birth weights. The authors concluded social support may promote higher birth weights. In addition to direct material provisions, social support may encourage expectant mothers to adopt healthier lifestyles, reduce their stress levels, and pursue better prenatal care. 


\section{Conclusion}

Additional research is needed to explore interventions with a systems-based approach to promote healthy maternal behaviors and improve care for expecting mothers living in poor quality neighborhood environments to reduce preterm births. One strategy is to increase the social capital of women living in poor quality neighborhood environments. Previous research reported those with high social capital are more likely to use adequate health care services. ${ }^{29}$ Individuals of a community with high social capital may provide one another with greater

\section{References}

${ }^{1}$ Centers for Disease Control and Prevention. About Healthy Places. 2010. Available at: http://www.cdc.gov/healthy places/about.htm. Accessed April 15, 2013.

2 Messer LC, Vinikoor LC, Laraia BA, et al. Socioeconomic domains and associations with preterm birth. Soc Sci Med 2008; 67(8):1247-1257. PMID: 18640759.

${ }^{3}$ Farley TA, Mason K, Rice J, Habel JD, Scribner R, Cohen DA. The relationship between the neighbourhood environment and adverse birth outcomes. Paediatr Perinat Epidemiol 2006; 20(3):188-200. PMID: 16629693.

4 Masi CM, Hawkley LC, Piotrowski ZH, Pickett KE. Neighborhood economic disadvantage, violent crime, group density, and pregnancy outcomes in a diverse, urban population. Soc Sci Med 2007; 65(12):2440-2457. PMID: 17765371.

${ }^{5}$ Hutch DJ, Bouye KE, Skillen E, Lee C, Whitehead L, Rashid JR. Potential strategies to eliminate built environment disparities for disadvantaged and vulnerable communities. Am J Public Health 2011; 101(4):587-595. PMID: 21389288. instrumental and psychosocial support than those of a community with low social capital. The community's level of interconnectedness and trust may reduce barriers to health care and mitigate negative health consequences associated with the built environment. A focus on the built environment with an emphasis on increasing the opportunities for healthy eating, physical activity, and early access to quality prenatal care has the potential to reduce maternal stress and improve birth outcomes of expectant mothers. ${ }^{30}$

${ }^{6}$ US Centers for Disease Control and Prevention. Designing and Building Healthy Places. 2007. Available at: http:// www.cdc.gov/healthyplaces/. Accessed April 15, 2013.

${ }^{7}$ Vinikoor-Imler LC, Messer LC, Evenson KR, Laraia BA. Neighborhood conditions are associated with maternal health behaviors and pregnancy outcomes. Soc Sci Med 2011; 73(9):1302-1311. PMID: 21920650.

${ }^{8}$ Geddes I, Allen J, Allen M, Morrisey L. The Marmot Review: Implications for Spatial Planning. 2011. Available at: http://www.nice.org.uk/nicemedia/live/12 111/53895/53895.pdf. Accessed February 17, 2014.

${ }^{9}$ US Centers for Disease Control and Prevention. Preterm Birth. 2013. Available at: http://www.cdc.gov/repro ductivehealth/MaternalInfantHealth/Preter mBirth.htm. Accessed April 15, 2013.

${ }^{10}$ Miranda ML, Messer LC, Kroeger GL. Associations between the quality of the residential built environment and pregnancy outcomes among women in North Carolina. Environ Health Perspect 2012; 120(3):471-477. PMID: 22138639.

${ }^{11}$ Zeka A, Melly SJ, Schwartz J. The effects of socioeconomic status and indices of 
physical environment on reduced birth weight and preterm births in Eastern Massachusetts. Environ Health 2008; 7:60. PMID: 19032747.

${ }^{12}$ Giurgescu C, Zenk SN, Dancy BL, Park CG, Dieber W, Block R. Relationships among neighborhood environment, racial discrimination, psychological distress, and preterm birth in African American women. J Obstet Gynecol Neonatal Nurs 2012; 41(6):E51-E61. PMID: 23030593.

${ }^{13}$ Metcalfe A, Lail P, Ghali WA, Sauve RS. The association between neighbourhoods and adverse birth outcomes: A systematic review and meta-analysis of multi-level studies. Paediatr Perinat Epidemiol 2011; 25(3):236-245. PMID: 21470263.

${ }^{14}$ Porta D, Milani S, Lazzarino AI, Perucci CA, Forastiere F. Systematic review of epidemiological studies on health effects associated with management of solid waste. Environ Health 2009; 8:60. PMID: 20030820.

${ }^{15}$ Šrám RJ, Binková B, Dejmek J, Bobak M. Ambient air pollution and pregnancy outcomes: A review of the literature. Environ Health Perspect 2005; 113(4): 375-382. PMID: 15811825.

${ }^{16}$ Shah PS, Balkhair T, Knowledge Synthesis Group on Determinants of Pertern/LWB births. Air pollution and birth outcomes: A systematic review. Environ Int 2011; 37(2):498-516. PMID: 21112090.

${ }^{17}$ Elliott P, Briggs D, Morris S, et al. Risk of adverse birth outcomes in populations living near landfill sites. BMJ 2001; 323(7309):363-368. PMID: 11509424.

${ }^{18}$ Petticrew M, Roberts H. Systematic reviews in the social sciences: A practical guide. Carlton, Victoria, Australia: Blackwell Publishing Ltd., 2006. ISBN: 1405121106.

${ }^{19}$ Schempf A, Strobino D, O'Campo P. Neighborhood effects on birthweight: An exploration of psychosocial and behavioral pathways in Baltimore, 1995-1996. Soc Sci Med 2009; 68(1):100-110. PMID: 18995941.

${ }^{20}$ Debbink MP, Bader MD. Racial residential segregation and low birth weight in Michigan's metropolitan areas. Am J Public Health 2011; 101(9):17141720. PMID: 21778487.

${ }^{21}$ Kramer MR, Cooper HL, Drews-Botsch CD, Waller LA, Hogue CR. Metropolitan isolation segregation and Black-White disparities in very preterm birth: A test of mediating pathways and variance explained. Soc Sci Med 2010; 71(12): 2108-2116. PMID: 20947234.

${ }^{22}$ Messer LC, Kaufman JS, Dole N, Savitz DA, Laraia BA. Neighborhood crime, deprivation, and preterm birth. Ann Epidemiol 2006; 16(6):455-462. PMID: 16290179.

${ }^{23}$ O'Campo P, Burke JG, Culhane J, et al. Neighborhood deprivation and preterm birth among non-Hispanic Black and White women in eight geographic areas in the United States. Am J Epidemiol 2008; 167(2):155-163. PMID: 17989062.

${ }^{24}$ Holzman C, Eyster J, Kleyn $\mathrm{M}$, et al. Maternal weathering and risk of preterm delivery. Am J Public Health 2009; 99(10):1864-1871. PMID: 19696383.

${ }^{25}$ Janevic T, Stein CR, Savitz DA, Kaufman JS, Mason SM, Herring AH. Neighborhood deprivation and adverse birth outcomes among diverse ethnic groups. Ann Epidemiol 2010; 20(6):445-451. PMID: 20470971.

${ }^{26}$ Behrman R, Butler A. (Eds.) Preterm Birth: Causes, Consequences, and Prevention. Washington, DC: National Academies Press, 2007. ISBN: 0-30910159-X.

${ }^{27}$ Iams JD, Romero R, Culhane JF, Goldenberg RL. Primary, secondary, and tertiary interventions to reduce the morbidity and mortality of preterm birth. 
Lancet 2008; 371(9607):164-175. PMID: 18191687.

${ }^{28}$ Hobel CJ, Goldstein A, Barrett ES. Psychosocial stress and pregnancy outcomes. Clin Obstet Gynecol 2008; 51(2):333-348. PMID: 18463464.

${ }^{29}$ Perry M, Williams RL, Wallerstein N, Waitzkin H. Social capital and health care experiences among low-income individuals. Am J Public Health 2008; 98(2):330336. PMID: 18172158.
${ }^{30}$ Nkansah-Amankra S, Luchok KJ, Hussey JR, Watkins K, Liu X. Effects of maternal stress on low birth weight and preterm birth outcomes across neighborhoods of South Carolina, 2000-2003. Matern Child Health J 2010; 14(2):215-226. PMID: 19184386.

Keywords: premature birth, maternal behavior, environment design 